\title{
Strain-dependent inhibitory effect of mutant mi-MITF on cytotoxic activities of cultured mast cells and natural killer cells of mice
}

\author{
Tatsuki R Kataoka, Eiichi Morii, Keisuke Oboki and Yukihiko Kitamura \\ Department of Pathology, Medical School/Graduate School of Frontier Bioscience, Osaka University, Osaka, \\ Japan
}

\begin{abstract}
MITF is a transcription factor encoded by the $m i$ locus. MITF encoded by $m i$ and $M i^{\text {ir }}$ mutant alleles ( $m i$-MITF and

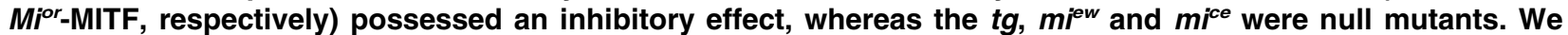
examined the cytotoxic activities of cultured mast cells (CMCs) and natural killer (NK) cells of various MITF mutants in C57BL/6 (B6) background. Cytotoxic activities of CMCs and NK cells of B6- $\mathrm{mi} / \mathrm{mi}$ and B6-Mior $/ \mathrm{Mi}^{\text {or }}$ mice were remarkably reduced. In B6-tg/tg, B6- $\mathrm{mi}^{\mathrm{ew}} / \mathrm{mi}^{\mathrm{ew}}$ and B6- $\mathrm{mi} \mathrm{c}^{\mathrm{ce}} / \mathrm{mi}^{\mathrm{ce}}$ mice, however, the cytotoxic activity of CMCs was reduced only slightly and the NK activity was normal. The cytotoxic activity of CMCs paralleled with the expression level of granzyme B (Gr B) mRNA, and the NK activity with that of perforin (Pfn) mRNA. In contrast to the case of B6-mi/mi mice, cytotoxic activities of CMCs and NK cells were not impaired in WB-mi/mi mice. The expression of Gr B mRNA was not reduced in CMCs of WB-mi/mi mice, and that of Pfn mRNA was not reduced in NK cells of WB- $\mathrm{mi} / \mathrm{mi}$ mice. WB-mi/mi mice appeared to have factor(s) compensating for the inhibitory effect of mi-MITF on the expression of Gr B and Pfn genes.
\end{abstract}

Laboratory Investigation (2004) 84, 376-384, advance online publication, 12 January 2004; doi:10.1038/labinvest.3700040

Keywords: MITF; mast cells; NK cells; killing activity; mouse genetic background

The mouse mi locus encodes a transcription factor belonging to the basic-helix-loop-helix-leucine zipper family (MITF). ${ }^{1,2}$ The $m i$ is the first found mutant allele encoding an abnormal MITF (miMITF), ${ }^{3,4}$ in which one out of four consecutive arginines is deleted in the basic domain. ${ }^{5,6}$ The $M i^{\text {or }}$

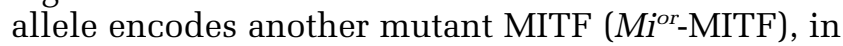
which one of four above-mentioned arginines in the basic domain changes to a lysine. ${ }^{5,6}$ The reported phenotypes of $\mathrm{Mi}^{\text {or }} / \mathrm{Mi}^{\text {or }}$ mice were comparable to or a little less severe than those of $\mathrm{mi} / \mathrm{mi}$ mice in C57BL/6 (B6) genetic background. ${ }^{7,8}$

Mice of $t g / t g$ genotype are null mutants at the $m i$ locus, a condition that was produced by transgene insertion into the $5^{\prime}$ flanking region of the mi gene. ${ }^{9}$ Both B6-tg/tg and B6- $\mathrm{mi} / \mathrm{mi}$ mice share a lot of abnormal phenotypic features, such as microphthalmia, white coat color and decreased number of mast cells. ${ }^{3,4,10-13}$ However, they were clearly distinguishable from each other at least in the following three respects: B6-mi/mi mice showed osteopetrosis, ${ }^{3,4}$ the

Correspondence: TR Kataoka, Department of Pahology, Room C2, Osaka University Medical School, Yamada-oka 2-2, Suita, Osaka 565-0871, Japan. E-mail: trkata@patho.med.osaka-u.ac.jp

Received 01 August 2003; revised 30 October 2003; accepted 20 November 2003; published online 12 January 2004 lack of cytotoxic activity of cultured mast cells (CMCs), ${ }^{13}$ and that of natural killer (NK) cells. ${ }^{14}$ On the other hand, B6-tg/tg mice did not show osteopetrosis, ${ }^{15}$ and NK cells and CMCs of $\mathrm{tg} / \mathrm{tg}$ mice did not show the decreased cytotoxic activity. ${ }^{13,14}$ The osteopetrosis and deficient cytotoxic activities of B6-mi/mi mice appeared to result from the inhibitory effect of mi-MITF. ${ }^{16}$

In the previous studies, we used mutant mice of $\mathrm{mi} / \mathrm{mi}, \mathrm{Mi}^{\text {or }} / \mathrm{Mi}^{\text {or }}$ or $\mathrm{tg} / \mathrm{tg}$ genotype in B6 genetic background. The effects of $m i^{\text {ew }}$ and $m i^{c e}$ mutations on phenotypes of CMCs were also investigated in B6 background. ${ }^{17,18}$ The $m i^{\text {ew }}$ mutant allele encodes the MITF without most part of the basic domain,, ${ }^{5,17}$ and the $m i^{c e}$ mutant allele encodes the MITF without most part of the zipper domain. ${ }^{5,18}$ No significant differences were observed in phenotypes of B6- $\mathrm{tg} / \mathrm{tg}$, B6- $m i^{e w} / m^{e w}$ and B6- $m i^{c e} / m^{c e}$ CMCs. ${ }^{17,18}$ Therefore, the $m i^{e w}$ and $m i^{c e}$ were considered to be null mutations. ${ }^{16}$ Previously, we showed the normal cytotoxic activity of $\mathrm{B} 6-\mathrm{mi}^{c e} / \mathrm{mi}^{c e} \mathrm{CMCs} .{ }^{18}$ In the present study, we extended this and confirmed that deficient cytotoxic activities of both CMCs and NK cells resulted from the inhibitory effect of mi-MITF and $\mathrm{Mi}^{\mathrm{or}}$-MITF in the B6 genetic background.

We reported that an appreciable expression of granzyme B $(\mathrm{Gr} B)$ is necessary for the cytotoxicity of 
CMCs, ${ }^{13}$ and that of perforin (Pfn) for the cytotoxicity of NK cells. ${ }^{14}$ CMCs of B6-mi/mi mice showed a deficient expression of $\mathrm{Gr} \mathrm{B}$ gene, ${ }^{13}$ and their NK cells showed a deficient expression of $\mathrm{Pfn}$ gene. ${ }^{14}$ We showed these results only in B6 genetic background. Recently, we found that the effect of MITF on gene expression of mast cells was different between mice of B6 genetic background and mice of WB genetic background. ${ }^{19} \mathrm{WB}$ strain was originally produced by Russell et $a 1^{20,21}$ to prolong the longevity of the anemic and mast celldeficient $W / W$ mice. Mice of WB strain are usually used for the study of mast cells. The expression of mouse mast cell protease (mMCP)-2, mMCP-4, mMCP-5 and Gr B genes was reduced in B6-mi/mi CMCs but not in WB-mi/mi CMCs, when compared with that of $+/+$ mice of each strain. ${ }^{19}$ Since the expression of $\mathrm{Gr}$ B was not deficient in WB-mi/mi CMCs, we examined in the present study the cytotoxic activity of their CMCs. We also examined the NK activity and the expression of Pfn gene in spleen cells of WB-mi/mi mice. We found and report here that mi-MITF did not inhibit cytotoxic activities of CMCs and NK cells in the genetic background of the WB strain.

\section{Materials and methods}

\section{Mice}

The origin of mutant $m i$, tg, $\mathrm{Mi}^{\mathrm{or}}$, $\mathrm{mi}^{\mathrm{ce}}$ and $m \mathrm{mi}^{\mathrm{ew}}$ alleles has been described previously.,17,18 B6-mi/ $\mathrm{mi}, \mathrm{B} 6-\mathrm{Mi}^{o r} / \mathrm{Mi}^{\text {or }}$, B6-tg/tg, B6-mice $/ \mathrm{mi}^{\mathrm{ce}}$ and B6-mi ${ }^{\text {ew }} /$ $m i^{\text {ew }}$ mice were produced in our laboratory in the background of our own inbred B6 colony. They were identified by the white coat color and small eyes.

The mi mutant allele was introduced into WB strain by repeated backcrosses. ${ }^{19}$ WB-mi/+ mice used in the present experiment were at 9th to 11th generations of the backcross. $(\mathrm{WB} \times \mathrm{B} 6) \mathrm{F}_{1}$ $\left(\mathrm{WBB}_{6} \mathrm{~F}_{1}\right)-\mathrm{mi} / \mathrm{mi}$ mice were obtained by mating between WB-mi/t and B6-mi/ + mice. Mice of $\mathrm{mi} / \mathrm{mi}$ genotype of each strain were identified by the white coat color.

\section{Cells}

YAC-1 cells were obtained from American Type Culture Collection (Bethesda, MD, USA) and maintained in $\alpha$-minimal essential medium ( $\alpha$-MEM; ICN Biomedicals, Costa Mesa, CA, USA) supplemented with $10 \%$ fetal calf serum (FCS; Nippon Bio-supp Center, Tokyo, Japan).

Mice of 2 weeks of age were used to obtain CMCs. Mice were killed by decapitation after ether anesthesia, and spleens were removed. To prepare spleen cell suspensions, spleens were passed through the mesh. Pokeweed mitogen-stimulated spleen cell conditioned medium (PWM-SCM) was prepared according to the method described by
Nakahata et al. ${ }^{22}$ Spleen cells were cultured in $\alpha$-MEM supplemented with $10 \%$ PWM-SCM and $10 \%$ FCS. Half of the medium was replaced every 5 days. More than $95 \%$ of cells contained alcian bluepositive granules and were considered to be CMCs 4 weeks after the initiation of the culture.

In some experiments, spleen cells were obtained $24 \mathrm{~h}$ after intraperitoneal injection of polyinosinicpolycytidylic acid (poly I:C) (Sigma, St Louis, MO, USA). Poly I:C $(100 \mu \mathrm{g})$ was resolved in $100 \mu \mathrm{l}$ of phosphate-buffered saline (PBS) and injected into each mouse. ${ }^{23,24}$ Spleen cells were centrifuged on Ficoll gradients (density $=1.077-1.080$ ) (ICN) at $200 \mathrm{~g}$ for $30 \mathrm{~min}$, and used as spleen mononuclear cells for the estimation of NK activity.

Cultured spleen cells were used as effector cells in other experiments. Spleen mononuclear cells $\left(5 \times 10^{4}\right)$ were suspended in $2 \mathrm{ml}$ of RPMI 1640 medium supplemented with $10 \%$ FCS, $1000 \mathrm{U} / \mathrm{ml}$ recombinant mouse interleukin 2 (rmIL-2) (R\&D Systems, Minneapolis, MN, USA) and $100 \mathrm{ng} / \mathrm{ml}$ rmIL-18 (MBL Co. Ltd, Nagoya, Japan) according to the method described by Tomura et al. ${ }^{25}$ Cells were incubated in 24-well culture plates (Corning 25860, Corning Glass Works, Corning, NY, USA) at $37^{\circ} \mathrm{C}$. The medium was replaced after 3 days of culture. Nonadherent cells were harvested and used 7 days after the initiation of culture.

\section{Cytotoxicity Assay}

Cytotoxicity of CMCs, spleen mononuclear cells and cultured spleen cells was measured as described previously. ${ }^{13,14}$ The target YAC- 1 cells $\left(5 \times 10^{6}\right)$ were labeled with $\left[{ }^{51} \mathrm{Cr}\right] \mathrm{Na}_{2} \mathrm{CrO}_{4}$ (Amersham-Pharmacia Biotech, Amersham Place, UK) for $2 \mathrm{~h}$, washed three times and resuspended in $\alpha$-MEM supplemented with $10 \%$ FCS. The effecter cells were washed, suspended in $\alpha$-MEM supplemented with $10 \%$ FCS, mixed with labeled YAC- 1 cells $\left(1 \times 10^{4}\right)$ at indicated ratio and plated into 96-well microtiter plates with round bottoms in triplicate. The cocultures with CMCs were continued for $18 \mathrm{~h},{ }^{26}$ and those with spleen mononuclear cells or cultured spleen cells for $4 \mathrm{~h},{ }^{27}$ at $37^{\circ} \mathrm{C}$ in a $\mathrm{CO}_{2}$ incubator. After incubation, plates were spun at $150 \mathrm{~g}$ for $10 \mathrm{~min}$ and the radioactivity was determined in $100 \mu \mathrm{l}$ samples of cell-free supernatants. The radioactivity released in the well containing YAC-1 cells alone was designated spontaneous release (SR). The total ${ }^{51} \mathrm{Cr}$ release (TR) was measured by adding $0.01 \%$ Triton $\mathrm{X}-100$ to the well containing YAC-1 cells alone. The percentage of specific ${ }^{51} \mathrm{Cr}$ release was calculated using the following formula: (cpm in the presence of cytotoxic cells $-\mathrm{SR}) /(\mathrm{TR}-\mathrm{SR}) \times 100$.

\section{Northern blot analysis}

Northern blot analysis was performed according to the standard method. ${ }^{28}$ Template complementary 
DNA (cDNA) for the probe was obtained by reversetranscription polymerase chain reaction (RT-PCR). The following oligonucleotides were used for PCR: the $\mathrm{Gr}$ B sense primer 5'-GATTACCCATCGTCCCTA GAGCT-3' and antisense primer 5'-CATGCCCAGCT CCAATGCAAAC- $3^{\prime}$; the perforin sense primer $5^{\prime}$ TGCCACTCGGTCAGAATGCAAGC- $3^{\prime}$ and antisense primer $5^{\prime}$-CTTCCAGTAATGTGTGCAGGGGC-3'; the $\beta$-actin sense primer $5^{\prime}$-TAAAGACCTCTATGCCAA CAC- $3^{\prime}$ and antisense primer $5^{\prime}$-CTCCTGCTTGCTG ATCCACAT- $3^{\prime}$.

\section{Fluorescence-Activated Cell Sorting (FACS) Analysis}

Spleen mononuclear cells of nontreated mice or cultured spleen cells were washed twice with cold PBS containing $0.5 \%$. bovine serum albumin and $0.1 \%$ sodium azide. The cells were first incubated with anti-NK1.1 monoclonal antibody (Pharmingen, San Diego, CA, USA) at $4^{\circ} \mathrm{C}$ for $30 \mathrm{~min}$, rinsed, stained with fluorescein isothiocynate-conjugated goat antimouse IgG and then analyzed by a FACScan (Becton Dickinson, Los Angeles, CA, USA).

\section{Morphological Examination}

Spleen mononuclear cells $\left(10^{5}\right)$ of nontreated mice or cultured spleen cells $\left(10^{5}\right)$ were centrifuged at $600 \mathrm{rpm}$ for $5 \mathrm{~min}$ onto microscope slides using a Cytospin 2 centrifuge (Shandon, Pittsburgh, PA, USA). Preparations were air-dried and fixed in methanol and stained with 10\% Giemsa solution (Merck, Darmstadt, Germany) diluted in Tris-buffered saline ( $\mathrm{pH}$ 6.4). Large granular lymphocytes (LGLs) were identified as being larger than smalland medium-sized lymphocytes. ${ }^{14,29,30}$ LGLs have a relatively high cytoplasmic-to-nuclear ratio and a weakly basophilic cytoplasm with several of azurophilic granules. Macrophages were distinguished from LGLs on the basis of their larger size, vacuolar cytoplasm and indented nucleus. To obtain the proportion of LGLs, at least 1000 spleen mononuclear cells were analyzed per slide and at least 200 cultured spleen cells were analyzed per slide.

\section{Results}

\section{Cytotoxicity of CMCs}

Spleen cells of B6- $+/+$, B6-mi/mi, B6-Mior $/ \mathrm{Mi}^{\text {or }}$, B6-tg/tg, B6- $\mathrm{mi}^{c e} / \mathrm{mi}^{c e}$ and B6- $\mathrm{mi}^{\mathrm{ew}} / \mathrm{mi}^{\mathrm{ew}}$ mice were cultured in the presence of PWM-SCM, and CMCs of each genotype were obtained. The cytotoxic activity of CMCs was evaluated by $16 \mathrm{~h}$ coculture with ${ }^{51} \mathrm{Cr}-$ labeled YAC-1 cells. ${ }^{51} \mathrm{Cr}$ release from YAC-1 cells was used as an index of the cytotoxic activity. CMCs of B6-+/+ mice showed a significant cytotoxic activity, but the cytotoxic activity of B6-mi/mi CMCs was not detectable (Table 1). The cytotoxic activity of B6-Mir $/ \mathrm{Mi}^{\text {or }} \mathrm{CMCs}$ was also severely impaired. The cytotoxicity of B6- $\mathrm{tg} / \mathrm{tg}, \mathrm{B} 6-\mathrm{mi}^{c e} / \mathrm{mi}^{\mathrm{ce}}$ and B6$m i^{\text {ew }} / \mathrm{mi}^{\text {ew }}$ CMCs was reduced only slightly when compared to the value of B6- + / + CMCs (Table 1).

In the next experiment, CMCs were obtained from the spleens of WB- $+/+, \mathrm{WB}-\mathrm{mi} / \mathrm{mi}$, $(\mathrm{WB} \times \mathrm{B} 6) \mathrm{F}_{1}$ $\left(\mathrm{WBB} \mathrm{F}_{1}\right)-+/+$ and $\mathrm{WBB} \mathrm{F}_{1}-\mathrm{mi} / \mathrm{mi}$ mice. In contrast to the result of CMCs derived from mice of $\mathrm{B} 6$ genetic background, $\mathrm{WB}-\mathrm{mi} / \mathrm{mi}$ and $\mathrm{WBB} \mathrm{F}_{1}-\mathrm{mi} / \mathrm{mi}$ CMCs did show cytotoxic activities that were comparable to those of $\mathrm{WB}-+/+$ and $\mathrm{WBB}^{-} \mathrm{F}_{1^{-}}+/+$ CMCs (Table 2).

Gr B and Pfn are major effector proteins of killing activity, but the expression of Pfn mRNA was not detectable even in B6- + / + CMCs. In CMCs of B6$\mathrm{tg} / \mathrm{tg}, \mathrm{B} 6-\mathrm{mi}^{\mathrm{ce}} / \mathrm{mi}^{\mathrm{ce}}$ and $\mathrm{B} 6-\mathrm{mi}^{\mathrm{ew}} / \mathrm{mi}^{\mathrm{ew}}$ mice, the amount of Gr B mRNA was reduced slightly when compared to the value of B6- $/$ + CMCs (Figure 1a). The expression of $\mathrm{Gr} B$ mRNA was remarkably reduced in B6-mi/mi and $\mathrm{B} 6-\mathrm{Mi}^{\text {or }} / \mathrm{Mi}^{\text {or }} \mathrm{CMCs}$ (Figure 1a). In contrast to the case of CMCs derived from mice of $\mathrm{B} 6$ background, the expression levels of $\mathrm{Gr} \mathrm{B}$ mRNA of WB-mi/mi and $\mathrm{WBB} \mathrm{F}_{1}-\mathrm{mi} / \mathrm{mi} \mathrm{CMCs}$ were comparable to those of $\mathrm{WB}-+/+$ and $\mathrm{WBB}^{-} \mathrm{F}_{1^{-}}+/+$ CMCs (Figure 1b).

\section{NK Activity}

Most of the B6-mi/mi, B6- $\mathrm{Mi}^{\text {or }} / \mathrm{Mi}^{\text {or }}$, WB-mi/mi and $\mathrm{WBB} \mathrm{F}_{1}-\mathrm{mi} / \mathrm{mi}$ mice die before 4 weeks of age due to the failure of teeth eruption. On the other hand,

Table 1 Cytotoxic activity of CMCs derived from B6-+/+, B6-mi/mi, B6- $\mathrm{Mi}^{\text {or }} / \mathrm{Mi}^{\text {or }}$, B6- $\mathrm{tg} / \mathrm{tg}$, B6- $\mathrm{mi}^{\mathrm{ce}} / \mathrm{mi}^{\mathrm{ce}}$ or B6-mi ${ }^{\text {ew }} / \mathrm{mi}^{\text {ew }} \mathrm{mice}$

\begin{tabular}{|c|c|c|c|c|c|c|}
\hline \multirow[t]{2}{*}{ E/T ratio } & \multicolumn{6}{|c|}{ Specific ${ }^{51} \mathrm{Cr}$ release (\%) by $18 \mathrm{~h}$ coculture ${ }^{a}$} \\
\hline & $B 6-+/+$ & $\mathrm{B} 6-\mathrm{mi} / \mathrm{mi}$ & $B 6-M^{o r} / M^{o r}$ & B6- $\operatorname{tg} / \operatorname{tg}$ & $B 6-m i^{c e} / m i^{c e}$ & $B 6-m i^{e w} / m i^{e w}$ \\
\hline 50 & $3.5 \pm 1.9(5)^{\dagger}$ & $<0.1(5)^{*}$ & $<0.1(3)^{*}$ & $3.4 \pm 0.9(4)^{\dagger}$ & $3.1 \pm 0.2(4)^{\dagger}$ & $3.7 \pm 0.3(4)^{\dagger}$ \\
\hline 100 & $14.1+1.8(5)^{\dagger}$ & $<0.1(5)^{*}$ & $<0.1(3)^{*}$ & $11.8+0.7(4)^{*, \dagger}$ & $12.4+1.2(4)^{\dagger}$ & $11.6 \pm 1.3(4)^{\dagger}$ \\
\hline 250 & $23.4 \pm 1.3(5)^{\dagger}$ & $<0.1(5)^{*}$ & $2.7 \pm 2.7(3)^{*}$ & $18.1 \pm 0.9(4)^{*, \dagger}$ & $18.2 \pm 1.4(4)^{*, \dagger}$ & $18.4 \pm 0.9(4)^{*, \dagger}$ \\
\hline
\end{tabular}

E/T ratio indicates the ratio of CMCs to YAC-1 cells.

${ }^{\mathrm{a}}$ Mean \pm s.e. The number of independent assays are shown within parentheses.

${ }^{*} P<0.05$ by $t$-test when compared with the value of $\mathrm{B} 6-+/+$ CMCs.

${ }^{\dagger} P<0.05$ by $t$-test when compared with the value of B6-mi/mi CMCs. 
Table 2 Cytotoxic activity of CMCs derived from $\mathrm{WB}-+/+$, WB-mi/mi, $\mathrm{WBB} \mathrm{F}_{1-+} /+$ or $\mathrm{WBB} \mathrm{F}_{1}-\mathrm{mi} / \mathrm{mi}$ mice

\begin{tabular}{|c|c|c|c|c|}
\hline \multirow[t]{2}{*}{ E/T ratio } & \multicolumn{4}{|c|}{ Specific ${ }^{51} \mathrm{Cr}$ release (\%) by $18 \mathrm{~h}$ coculture ${ }^{a}$} \\
\hline & $W B-+/+$ & $W B-m i / m i$ & $W B B 6 F_{1-+} /+$ & $W B B 6 F_{1}-m i / m i$ \\
\hline 50 & $12.6 \pm 0.8(3)$ & $11.6 \pm 1.0(3)$ & $11.3 \pm 1.0(3)$ & $9.7 \pm 1.3(3)$ \\
\hline 100 & $17.2 \pm 1.0$ & $15.0 \pm 1.3$ & $14.9 \pm 1.2$ & $13.9 \pm 1.0$ \\
\hline 250 & $21.7 \pm 1.0(3)$ & $20.2 \pm 1.3(3)$ & $20.0 \pm 1.2(3)$ & $18.7 \pm 1.2(3)$ \\
\hline
\end{tabular}

$\mathrm{E} / \mathrm{T}$ ratio indicates the ratio of CMCs to YAC-1 cells.

${ }^{a}$ Mean \pm s.e. The number of independent assays are shown within parentheses. Significant difference $(P<0.05$ by $t$-test $)$ was not detectable between values of $+/+$ and $\mathrm{mi} / \mathrm{mi}$ mice of the same genetic background.

a

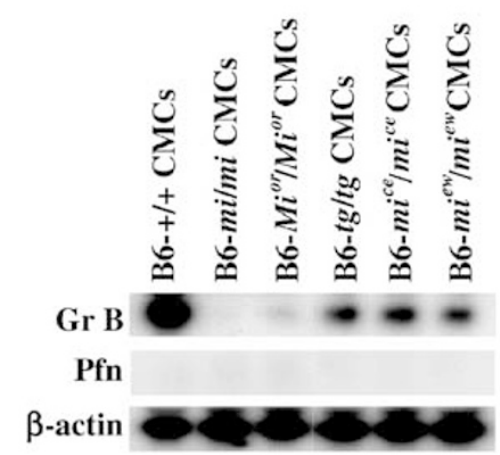

b

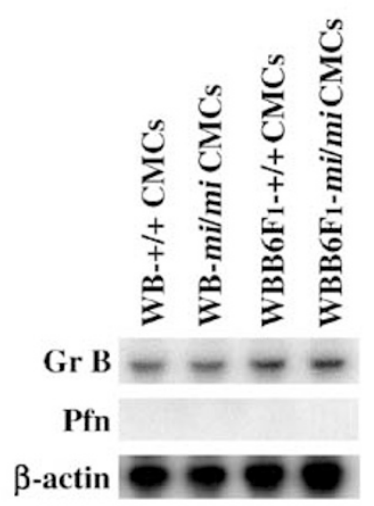

Figure 1 Expression of $\mathrm{Gr} \mathrm{B}$ and $\mathrm{Pfn}$ genes in CMCs derived from B6- $+l+$, B6-mi/mi, B6-Mi ${ }^{o r} / \mathrm{Mi}^{o r}$, B6- $t g / t g, \mathrm{~B} 6-m i^{c e} / \mathrm{mi}^{c e}$, B6-miew $/ \mathrm{mi}^{\mathrm{ew}}$, WB- $+/+$, WB-mi/mi, $\mathrm{WBB}^{2} \mathrm{~F}_{1}-+/+$ and $\mathrm{WBB}^{-} \mathrm{F}_{1}$ ' $\mathrm{mi} / \mathrm{mi}$ mice. Expression of Gr B and Pfn genes was examined by Northern blot. Total RNA ( $5 \mu \mathrm{g}$ ) was blotted and hybridized with ${ }^{32}$ P-labeled cDNA probe of Gr B and Pfn. Three independent experiments were carried out, and comparable results were obtained. A representative experiments is shown. (a) Expression of $\mathrm{Gr} \mathrm{B}$ and $\mathrm{Pfn}$ genes in $\mathrm{B} 6-+/+, \mathrm{B} 6-\mathrm{mi} / \mathrm{mi}$, B6-Mir $/ \mathrm{Mi}^{\text {or }}$, B6- $t g / t g, B 6-m i^{c e} / m i^{c e}$ and B6-miew $/ m i^{e w}$ CMCs. (b) The expression of $\mathrm{Gr} \mathrm{B}$ and Pfn genes in WB- $+/+, \mathrm{WB}-\mathrm{mi} / \mathrm{mi}$, $\mathrm{WBB}^{-} \mathrm{F}_{1^{-}}+/+$ and $\mathrm{WBB} \mathrm{F}_{1}-\mathrm{mi} / \mathrm{mi}$ CMCs.

mice of more than 6 weeks of age are generally used for assessment of NK activity. ${ }^{31}$ To obtain mice of $\mathrm{mi} / \mathrm{mi}$ genotype of 6 weeks of age, we fed weaning B6-mi/mi, B6-Mior $/ \mathrm{Mi}^{\text {or }}$, WB-mi/mi and $\mathrm{WBB}^{-} \mathrm{F}_{1}{ }^{-}$ $\mathrm{mi} / \mathrm{mi}$ mice with powdered chow. Spleen mononuclear cells derived from mice of 6 weeks of age were used.

Intraperitoneal injection of poly I:C induces IFN$\alpha / \beta$ secretion, enhances the expression of $\mathrm{Gr} B$ and Pfn genes in spleen cells and increases NK activity. ${ }^{14,23,24}$ Since the expression of $\mathrm{Gr} B$ and Pfn mRNAs was barely detectable in spleen cells of B6$+/+$ mice without poly I:C injection, ${ }^{14}$ we obtained spleen cells of B6- $+/+$, B6-mi/mi, B6- $\mathrm{Mi}^{\text {or }} / \mathrm{Mi}^{\text {or }}$, B6$\mathrm{tg} / \mathrm{tg}, \mathrm{B} 6-\mathrm{mi}^{\mathrm{ce}} / \mathrm{mi}^{c e}$ and $\mathrm{B} 6-\mathrm{mi}^{\mathrm{ew}} / \mathrm{mi}^{\mathrm{ew}}$ mice after intraperitoneal injection of poly I:C. Mononuclear cell fractions were taken by the centrifugation on Ficoll gradients, and cytotoxic activity was estimated by $4 \mathrm{~h}$ coculture with ${ }^{51} \mathrm{Cr}$-labeled YAC-1 cells. Spleen mononuclear cells of poly I:C-treated B6- $+/+$ mice showed significant cytotoxicity (Table 3). Cytotoxic activity of spleen mononuclear cells of B6- $\mathrm{tg} / \mathrm{tg}, \mathrm{B} 6-\mathrm{mi}^{\mathrm{ce}} / \mathrm{mi}^{\mathrm{ce}}$ and $\mathrm{B} 6-\mathrm{mi} \mathrm{i}^{\mathrm{ew}} / \mathrm{mi}^{\mathrm{ew}}$ mice was comparable to that of $\mathrm{B} 6-+/+$ spleen mononuclear cells, but the cytotoxic activity of spleen mononuclear cells of B6-mi/mi and B6- $\mathrm{Mi}^{\text {or }} / \mathrm{Mi}^{\text {or }}$ mice was severely impaired (Table 3 ).

We examined the expression of Gr B and Pfn genes in spleen mononuclear cells with Northern hybridization. After the injection of poly I:C, the expression of Gr B mRNA was detectable in spleen mononuclear cells of B6 mice of all examined genotypes (Figure 2). However, the expression of Pfn gene was only faintly detectable in spleen mononuclear cells of $\mathrm{B} 6-\mathrm{mi} / \mathrm{mi}$ and $\mathrm{B} 6-\mathrm{Mi}^{\text {or }} / \mathrm{Mi}^{\text {or }}$ mice even after the injection of poly I:C (Figure 2).

In the next experiment, we obtained spleen mononuclear cells from $\mathrm{WB}-+/+$, WB-mi $/ \mathrm{mi}$, $\mathrm{WBB} \mathrm{F}_{1^{-}}+/+$and $\mathrm{WBB} \mathrm{F}_{1}-\mathrm{mi} / \mathrm{mi}$ mice with or without poly I:C injection. The cytotoxic activity of spleen mononuclear cells of $\mathrm{WB}-\mathrm{mi} / \mathrm{mi}$ and $\mathrm{WBB} \mathrm{F}_{1}-\mathrm{mi} / \mathrm{mi}$ mice that did not receive poly I:C injection was comparable to that of spleen mononuclear cells of the control WB- $+/+$ and $\mathrm{WBB} \mathrm{F}_{1}-$ $+/+$ mice (Table 4). The injection of poly I:C augmented the cytotoxic activity of spleen mononuclear cells of all examined mice, but no significant differences were observed between spleen mononuclear cells of $\mathrm{WB}-+/+$ and $\mathrm{WB}-\mathrm{mi} / \mathrm{mi}$ mice and between those of $\mathrm{WBB}^{-} \mathrm{F}_{1^{-}}+/+$and $\mathrm{WBB}^{-} \mathrm{F}_{1^{-}}$ $\mathrm{mi} / \mathrm{mi}$ mice (Table 4). 
Table 3 Cytotoxic activity of spleen mononuclear cells derived from B6-+/+, B6-mi/mi, B6- $\mathrm{Mi}^{o r} / \mathrm{Mi}^{\text {or }}$, B6-tg/tg, B6-mice $/ \mathrm{mi}^{c e}$ or B6- $m i^{e w} / m i^{e w}$ mice which received poly I:C injection

\begin{tabular}{|c|c|c|c|c|c|c|}
\hline \multirow[t]{2}{*}{ E/T ratio } & \multicolumn{6}{|c|}{ Specific ${ }^{51} \mathrm{Cr}$ release (\%) by $4 \mathrm{~h}$ coculture ${ }^{a}$} \\
\hline & $B 6-+/+$ & $\mathrm{B} 6-\mathrm{mi} / \mathrm{mi}$ & $B 6-M i^{o r} / M i^{o r}$ & B6-tg/tg & $B 6-m i^{i c e} / m i^{c e}$ & $B 6-m i^{e w} / m i^{e w}$ \\
\hline 10 & $9.2 \pm 0.9(3)^{*}$ & $2.3 \pm 0.4(3)^{\dagger}$ & $1.8 \pm 0.3(3)^{\dagger}$ & $7.5 \pm 0.4(3)^{*}$ & $10.8 \pm 1.2(3)^{*}$ & $9.0 \pm 1.2(3)^{*}$ \\
\hline 40 & $26.3 \pm 1.3(3)^{*}$ & $4.3 \pm 0.2(3)^{\dagger}$ & $3.8 \pm 0.7(3)^{\dagger}$ & $25.2 \pm 0.6(3)^{*}$ & $24.2 \pm 1.0(3)^{*}$ & $25.1 \pm 1.0(3)^{*}$ \\
\hline 75 & $40.7 \pm 1.3(3)^{*}$ & $8.1 \pm 0.4(3)^{\dagger}$ & $7.8 \pm 1.0(3)^{\dagger}$ & $38.9 \pm 1.1(3)^{*}$ & $39.5 \pm 1.1(3)^{*}$ & $37.4 \pm 0.8(3)^{*}$ \\
\hline
\end{tabular}

$\mathrm{E} / \mathrm{T}$ ratio indicates the ratio of spleen mononuclear cells to YAC-1 cells.

${ }^{\mathrm{a}}$ Mean \pm s.e. The number of independent assays are shown within parentheses.

${ }^{*} P<0.05$ by $t$ test when compared with the value of spleen mononuclear cells of B6- $\mathrm{mi} / \mathrm{mi}$ mice.

${ }^{\dagger} P<0.05$ by $t$ test when compared with the value of spleen mononuclear cells of B6-+/+ mice.

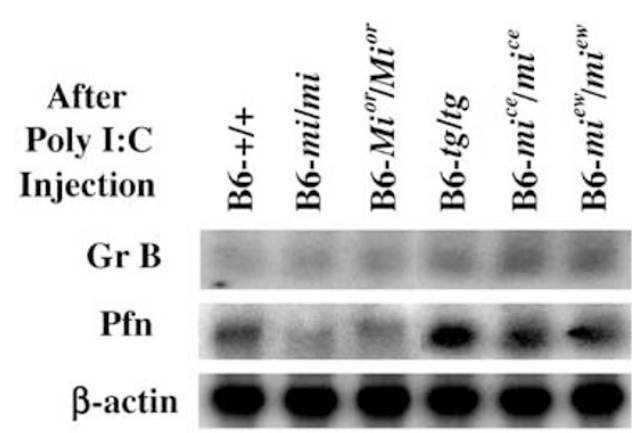

Figure 2 Expression of $\mathrm{Gr} \mathrm{B}$ and Pfn genes in spleen mononuclear cells derived from B6- + / +, B6-mi/mi, B6- $\mathrm{Mi}^{\text {or }} / \mathrm{Mi}^{\text {or }}$, B6-tg/tg, B6$m i^{c e} / \mathrm{mi}^{c e}$, B6-miew $/ \mathrm{mi}^{\text {ew }}$ mice that received poly I:C injection. Expression of Gr B and Pfn genes was examined by Northern blot. Total RNA $(20 \mu \mathrm{g})$ was blotted and hybridized with ${ }^{32}$ P-labeled cDNA probe of Gr B and Pfn. Three independent experiments were carried out, and comparable results were obtained. A representative experiment is shown.

We examined the expression of $\mathrm{Gr} B$ and Pfn genes in spleen mononuclear cells of $\mathrm{WB}-+/+$, $\mathrm{WB}-\mathrm{mi} / \mathrm{mi}$, $\mathrm{WBB} \mathrm{F}_{1^{-}}+/+$and $\mathrm{WBB}^{-} \mathrm{F}_{1}-\mathrm{mi} / \mathrm{mi}$ mice with Northern hybridization. In the spleen mononuclear cells derived from nontreated mice of all groups, the expression of Gr B and Pfn mRNAs was only faintly detectable (Figure 3). After the injection of poly I:C, the expression of Gr B and Pfn mRNAs was apparent in spleen mononuclear cells of all examined groups of mice (Figure 3). No significant differences were observed between mice of $+/+$ and $\mathrm{mi} / \mathrm{mi}$ genotypes.

Spleen cells obtained from B6- $+/+$, B6- $\mathrm{mi} / \mathrm{mi}$, $\mathrm{WB}-+/+$, WB-mi/mi, $\mathrm{WBB} \mathrm{F}_{1^{-}+}+/+$and $\mathrm{WBB}^{-} \mathrm{F}_{1}-$ $\mathrm{mi} / \mathrm{mi}$ mice were cultured with rmIL-2 and rmIL$18 .^{25}$ The cytotoxicity of these cultured spleen cells was evaluated. The cytotoxic activity of B6-mi/mi cultured spleen cells was severely impaired when compared to that of B6- $+/+$ cultured spleen cells, but the cytotoxic activities of cultured spleen cells of $\mathrm{WB}-\mathrm{mi} / \mathrm{mi}$ and $\mathrm{WBB} \mathrm{F}_{1}-\mathrm{mi} / \mathrm{mi}$ mice were comparable to the values of $\mathrm{WB}-+/+$ and $\mathrm{WBB}^{-} \mathrm{F}_{1^{-}}+/+$ mice, respectively (Table 5).

The expression of Gr B gene was comparable among cultured spleen cells of all $\mathrm{B} 6-+/+$, B6-mi/mi, WB- $+/+$, WB-mi/mi, $\mathrm{WBB}^{-} \mathrm{F}_{1^{-}}+/+$ and $\mathrm{WBB}_{6} \mathrm{~F}_{1}-\mathrm{mi} / \mathrm{mi}$ mice (Figure 4 ). The expression of Pfn gene was markedly impaired in B6-mi/micultured spleen cells, but normal in WB-mi/mi and $\mathrm{WBB} \mathrm{F}_{1}-\mathrm{mi} / \mathrm{mi}$-cultured spleen cells (Figure 4).

\section{Phenotypes of NK Cells}

We assessed the proportion of NK $1.1^{+}$cells by the FACScan in the spleen mononuclear cells of nontreated mice and in the cultured spleen cells. Spleen cells were obtained from B6- $+/+$, B6-mi/mi, WB$+/+, \mathrm{WB}-\mathrm{mi} / \mathrm{mi}$, $\mathrm{WBB} \mathrm{F}_{1^{-}}+/+$and $\mathrm{WBB}^{-} \mathrm{F}_{1}-\mathrm{mi} /$ mi mice at 6 weeks of age. The proportion of NK $1.1^{+}$cells was $\sim 2 \%$ in spleen mononuclear cells derived from all examined groups of mice (Table 6). After culture in the presence of rmIL-2 and rmIL-18, the proportion of NK $1.1^{+}$cells increased to $>80 \%$ of the total cells in all examined mice (Table 6). There were no significant differences among the proportions of $\mathrm{NK} 1.1^{+}$cells of all examined genotypes in the nontreated spleen mononuclear cells and in the cultured spleen cells (Table 6). The expression of NK 1.1 antigen did not appear to correlate to NK activity.

Next, we determined the proportion of LGLs in the spleen mononuclear cells of nontreated mice and in the cultured spleen cells. The proportion of LGLs was $\sim 1 \%$ in the spleen mononuclear cells of nontreated $\mathrm{B} 6-+/+$, $\mathrm{WB}-+/+$, WB-mi/mi, $\mathrm{WBB} \mathrm{F}_{1}-+/+$ and $\mathrm{WBB}^{-} \mathrm{F}_{1}-\mathrm{mi} / \mathrm{mi}$ mice, and it increased to $>70 \%$ after the culture (Table 6 , Figure 5). LGLs were not detectable in spleen mononuclear cells of the nontreated B6- $\mathrm{mi} / \mathrm{mi}$ mice (Table 6). Even after the culture of spleen cells of B6$\mathrm{mi} / \mathrm{mi}$ mice with rmIL-2 and rmIL-18, the proportion of LGLs remained $\sim 6 \%$, and was remarkably less than the values observed in the cultured spleen cells of B6- $+/+, \mathrm{WB}-+/+$, WB-mi/mi, $\mathrm{WBB}^{-} \mathrm{F}_{1^{-}}+/+$ and $\mathrm{WBB} \mathrm{F}_{1}-\mathrm{mi} / \mathrm{mi}$ mice (Table 6, Figure 5).

\section{Discussion}

Abundant mutant alleles have been reported at the mi locus. ${ }^{1,2}$ In addition to the loss of transactivation ability, the MITF encoded by $\mathrm{mi}$ and $\mathrm{Mi}^{\text {or }}$ alleles (miMITF and $\mathrm{Mi}^{\text {or }}$-MITF, respectively) possesses an inhibitory effect on the transcription of some 
Table 4 Cytotoxic activity of spleen mononuclear cells derived from WB-+/+, WB-mi/mi, $\mathrm{WBB} \mathrm{F}_{1}-+/+$ or $\mathrm{WBB}^{-} \mathrm{F}_{1}-\mathrm{mi} / \mathrm{mi}$ mice with or without poly I:C injection

\begin{tabular}{|c|c|c|c|c|c|}
\hline \multirow[t]{2}{*}{ Poly I:C injection } & \multirow[t]{2}{*}{ E/T ratio } & \multicolumn{4}{|c|}{ Specific ${ }^{51} \mathrm{Cr}$ release (\%) by $4 \mathrm{~h}$ coculture ${ }^{a}$} \\
\hline & & $W B-+/+$ & $W B-m i / m i$ & $W B B 6 F_{1-+} /+$ & $W B B 6 F_{1}-m i / m i$ \\
\hline \multirow[t]{3}{*}{ No } & 10 & $7.9 \pm 0.7(3)$ & $10.2 \pm 2.9$ & $8.3 \pm 1.3$ & $7.5 \pm 0.2(4)$ \\
\hline & 40 & $17.0 \pm 1.5(3)$ & $21.8 \pm 3.1$ (3) & $16.5 \pm 1.1(4)$ & $16.3 \pm 1.1(4)$ \\
\hline & 75 & $31.4 \pm 2.1$ (3) & $37.8 \pm 3.1$ (3) & $32.5 \pm 0.5(4)$ & $30.4 \pm 1.8$ \\
\hline \multirow[t]{3}{*}{ Yes } & 10 & $16.6 \pm 5.6(3)$ & $13.6 \pm 3.8(3)$ & $16.7 \pm 2.3(6)$ & $14.6 \pm 3.2(6)$ \\
\hline & 40 & $30.3 \pm 3.3$ & $30.8 \pm 4.3(3)$ & $30.6 \pm 1.4(6)$ & $27.4 \pm 1.6(6)$ \\
\hline & 75 & $52.1 \pm 2.5(3)$ & $47.9 \pm 5.8(3)$ & $52.5 \pm 1.3(6)$ & $47.2 \pm 1.4(6)$ \\
\hline
\end{tabular}

E/T ratio indicates the ratio of spleen mononuclear cells to YAC-1 cells.

${ }^{\mathrm{a}}$ Mean \pm s.e. The number of independent assays are shown in parentheses. Significant difference $(P<0.05$ by $t$-test $)$ was not detectable between values of $+/+$ and $\mathrm{mi} / \mathrm{mi}$ mice of the same genetic background.

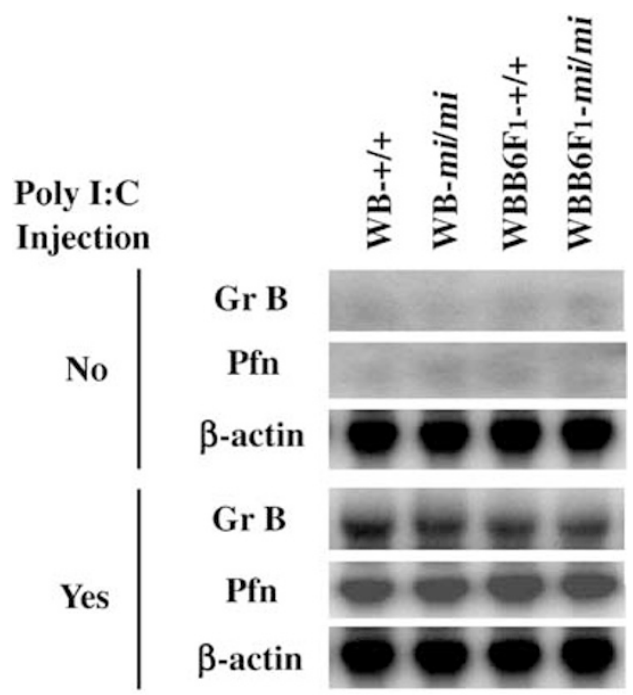

Figure 3 Expression of Gr B and Pfn genes in spleen mononuclear cells derived from $\mathrm{WB}-+/+, \mathrm{WB}-\mathrm{mi} / \mathrm{mi}$, $\mathrm{WBB} \mathrm{F}_{1^{-}}+/+$and $\mathrm{WBB} \mathrm{F}_{1}-\mathrm{mi} / \mathrm{mi}$ mice with or without poly I:C treatment. Expression of Gr B and Pfn genes was examined by Northern blot. Total RNA $(20 \mu \mathrm{g})$ was blotted and hybridized with ${ }^{32}$ P-labeled cDNA probe of Gr B and Pfn. Three independent experiments were carried out, and comparable results were obtained. A representative experiment is shown.

particular genes in mast cells. ${ }^{16}$ The $t g, \mathrm{mi}^{\mathrm{ew}}$ and $m i^{c e}$ mutant alleles were considered to be null mutant alleles. ${ }^{9,17,18}$ We examined the cytotoxicity of CMCs and NK cells of these mi mutant mice in B6 genetic background. Cytotoxicities of B6- $\mathrm{mi} / \mathrm{mi}$ and B6- $\mathrm{Mi}^{\text {or }} /$ $\mathrm{Mi}^{\text {or }}$ CMCs were significantly reduced when compared with those of B6- $+/+$ mice, whereas those of B6-tg/tg, B6-miew $/ m i^{e w}$ and B6- $m i^{c e} / \mathrm{mi}^{c e}$ CMCs were reduced only slightly. NK activities of B6- $\mathrm{mi} / \mathrm{mi}$ and B6- $\mathrm{Mi}^{\text {or }} / \mathrm{Mi}^{\text {or }}$ mice were remarkably impaired, but those of $\mathrm{B} 6-\mathrm{tg} / \mathrm{tg}, \mathrm{B} 6-\mathrm{mi}^{\mathrm{ew}} / \mathrm{mi}^{\mathrm{ew}}$ and $\mathrm{B} 6-\mathrm{mi}^{\mathrm{ce}} / \mathrm{mi}^{\mathrm{ce}}$ mice were normal. The cytotoxic activity of CMCs paralleled with the expression level of Gr B gene, and the NK activity with that of Pfn gene. These results indicated that decreased cytotoxicities of CMCs and NK cells of B6- $\mathrm{mi} / \mathrm{mi}$ and B6- $\mathrm{Mi}^{\text {or }} / \mathrm{Mi}^{\text {or }}$ mice were attributable to the inhibitory effect of $\mathrm{mi}$ MITF and $\mathrm{Mi}^{\text {or-MITF }}$ on transactivation of Gr B and Pfn genes, respectively.

Then, we examined the effect of mi-MITF on cytotoxicities of CMCs and NK cells in WB and $\mathrm{WBB}_{6} \mathrm{~F}_{1}$ mice. In contrast to the case of B6-mi/mi mice, the cytotoxic activity of CMCs of WB-mi/mi and $\mathrm{WBB} \mathrm{F}_{1}-\mathrm{mi} / \mathrm{mi}$ mice was not impaired. The expression of $\mathrm{Gr}$ B mRNA of $\mathrm{WB}-\mathrm{mi} / \mathrm{mi}$ and $\mathrm{WBB} \mathrm{F}_{1}-\mathrm{mi} / \mathrm{mi} \mathrm{CMCs}$ was not impaired, either. Moreover, the NK activity and the expression of Pfn mRNA were not impaired in spleen mononuclear cells and cultured spleen cells of WB-mi/mi

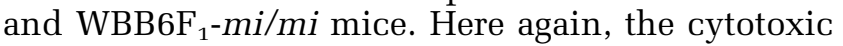
activity of CMCs paralleled with the expression level of Gr B gene and the NK activity with that of Pfn gene.

The different effect of mi-MITF between B6 and WB strains was firstly found in skin mast cells. ${ }^{19}$ The number of skin mast cells significantly decreased in B6-mi/mi mice when compared to B6- + / + mice. However, it did not decrease in WB-mi/mi mice when compared to WB- $+/+$ mice. The skin of WB strain contained a larger amount of soluble Kit ligand (KitL) that was important for the growth of mast cells, as compared to the skin of B6 strain. ${ }^{19,32,33}$ The large amount of soluble KitL compensated the effect of mi-MITF on the number of skin mast cells in WB strain. The results of the present study revealed that the expression of Gr B and $\mathrm{Pfn}$ genes was reduced in B6-mi/mi mice but not in WB-mi/mi mice. These indicated that the factor(s) compensating the inhibitory effect of mi-MITF on the expression of Gr B and Pfn genes was present in mice of WB strain but not in mice of B6 strain. In T cells, activator protein (AP)-1 and polyomavirus enhancer-binding protein 2 (PEBP2) are essential transcription factors for the expression of Gr B gene. ${ }^{34}$ We previously reported that MITF 
Table 5 Cytotoxic activity of spleen cells of B6-+/+, B6-mi/mi, WB-+/+, WB-mi/mi, WBB6F $1^{-+} /+$or $\mathrm{WBB} \mathrm{F}_{1}-\mathrm{mi} / \mathrm{mi} \mathrm{mice}$ cultured in the presence of mouse IL-2 and IL-18 for 7 days

\begin{tabular}{|c|c|c|c|c|c|c|}
\hline \multirow[t]{2}{*}{ E/T ratio } & \multicolumn{6}{|c|}{ Specific ${ }^{51} \mathrm{Cr}$ release (\%) by $4 \mathrm{~h}$ coculture ${ }^{a}$} \\
\hline & $B 6-+/+$ & $\mathrm{B} 6-\mathrm{mi} / \mathrm{mi}$ & $W B-+/+$ & $W B-m i / m i$ & $W B B 6 F_{1-+} /+$ & $W B B 6 F_{1}-m i / m i$ \\
\hline 10 & $13.3 \pm 1.1$ & $6.8 \pm 1.2(3)^{*}$ & $12.2 \pm 0.8$ & $11.0 \pm 0.9$ & $14.8 \pm 1.1(3)$ & $11.9 \pm 1.2(3)$ \\
\hline 40 & $30.6 \pm 1.6$ & $10.6 \pm 1.0(3)^{*}$ & $25.6 \pm 0.9(3)$ & $24.9 \pm 1.0$ & $29.6 \pm 1.4(3)$ & $27.2 \pm 1.3(3)$ \\
\hline 75 & $66.3 \pm 1.2(3)$ & $14.3 \pm 0.8(3)^{*}$ & $62.9 \pm 0.9$ & $61.7 \pm 1.2$ & $68.4 \pm 1.4(3)$ & $66.3 \pm 1.3(3)$ \\
\hline
\end{tabular}

E/T ratio indicates the ratio of spleen mononuclear cells to YAC-1 cells.

${ }^{\mathrm{a}}$ Mean \pm s.e. The number of independent assays are shown within parentheses.

$* P<0 . \overline{05}$ by $t$-test when compared with the value of cultured spleen cells of $+1+$ mice of the same genetic background.

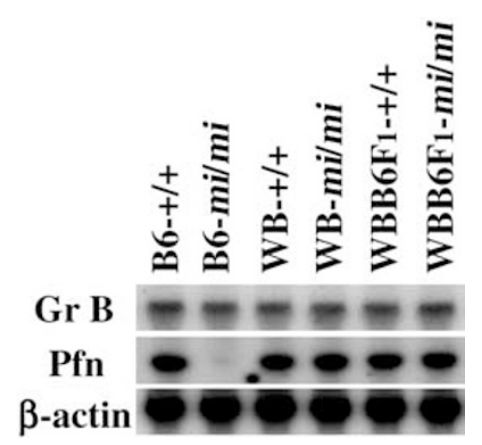

Figure 4 Expression of Gr B and Pfn genes in cultured spleen cells derived from B6- $+/+$, B6-mi/mi, WB- $+/+$, WB-mi $/ \mathrm{mi}$, $\mathrm{WBB} \mathrm{F}_{1}-+/+$ and $\mathrm{WBB} \mathrm{F}_{1}-\mathrm{mi} / \mathrm{mi}$ mice. Expression of Gr B and Pfn genes was examined by Northern blot. Total RNA $(10 \mu \mathrm{g})$ was blotted and hybridized with ${ }^{32} \mathrm{P}$-labeled cDNA probe of Gr B and Pfn. Three independent experiments were carried out, and comparable results were obtained. A representative experiment is shown.

Table 6 Proportion of NK1.1+ cells and LGLs in spleen mononuclear cells and in cultured spleen cells of B6-+/+, B6- $\mathrm{mi} / \mathrm{mi}$, $\mathrm{WB}-+/+$, WB- $m i / m i, \mathrm{WBB} \mathrm{F}_{1-+}++$ and $\mathrm{WB} \mathrm{B} 6 \mathrm{~F}_{1}-\mathrm{mi} / \mathrm{mi}$ mice

\begin{tabular}{|c|c|c|c|c|}
\hline \multirow[t]{2}{*}{$\begin{array}{l}\text { Origin of } \\
\text { spleen cells }\end{array}$} & \multicolumn{2}{|c|}{$\begin{array}{c}\text { Proportion of } N K 1.1^{+} \\
\text {cells }(\%)^{a}\end{array}$} & \multicolumn{2}{|c|}{ Proportion of LGLs $(\%)^{a}$} \\
\hline & $\begin{array}{c}\text { Spleen } \\
\text { mononuclear } \\
\text { cells }^{b}\end{array}$ & $\begin{array}{l}\text { Cultured } \\
\text { spleen } \\
\text { cells }\end{array}$ & $\begin{array}{c}\text { Spleen } \\
\text { mononuclear } \\
\text { cells }^{b}\end{array}$ & $\begin{array}{l}\text { Cultured } \\
\text { spleen } \\
\text { cells }\end{array}$ \\
\hline B6-+/+ & $2.1 \pm 0.3$ & $82 \pm 2(3)$ & $1.3 \pm 0.2(3)$ & $75 \pm 5(4)$ \\
\hline $\mathrm{B} 6-\mathrm{mi} / \mathrm{mi}$ & $1.8+0.3(3)$ & $82+1(3)$ & $<0.1(3)^{*}$ & $6+3(4)^{*}$ \\
\hline WB-+/+ & $1.9 \pm 0.5(3)$ & $82 \pm 3(3)$ & $1.0 \pm 0.1(3)$ & $78 \pm 3(4)$ \\
\hline WB-mi/mi & $2.0+0.3(3)$ & $81+3(3)$ & $0.8+0.3(3)$ & $74+4(4)$ \\
\hline $\mathrm{WBB} \mathrm{F}_{1-+}+{ }_{+}$ & $2.1 \pm 0.4(3)$ & $80 \pm 2(3)$ & $1.1 \pm 0.3(3)$ & $78 \pm 5(4)$ \\
\hline $\mathrm{WBB} \mathrm{F}_{1}-\mathrm{mi} / \mathrm{mi}$ & $2.0 \pm 0.2(3)$ & $81 \pm 2(3)$ & $0.9 \pm 0.2(3)$ & $76 \pm 4(4)$ \\
\hline
\end{tabular}

${ }^{\mathrm{a}}$ Mean \pm s.e. (\%). Then umber of independent evaluations are shown within parentheses.

${ }^{\mathrm{b}}$ Spleen cells were obtained from nontreated mice.

${ }^{*} P<0.01$ by $t$ test when compared with the value of $+/+$ mice of the same genetic background.

interacted with AP- $1^{35}$ and PEBP $2 .{ }^{36}$ The mi-MITF may inhibit the function of AP-1 and/or PEBP2 in B6 mice but not in $\mathrm{WB}$ and $\mathrm{WBB} \mathrm{F}_{1}$ mice owing to the

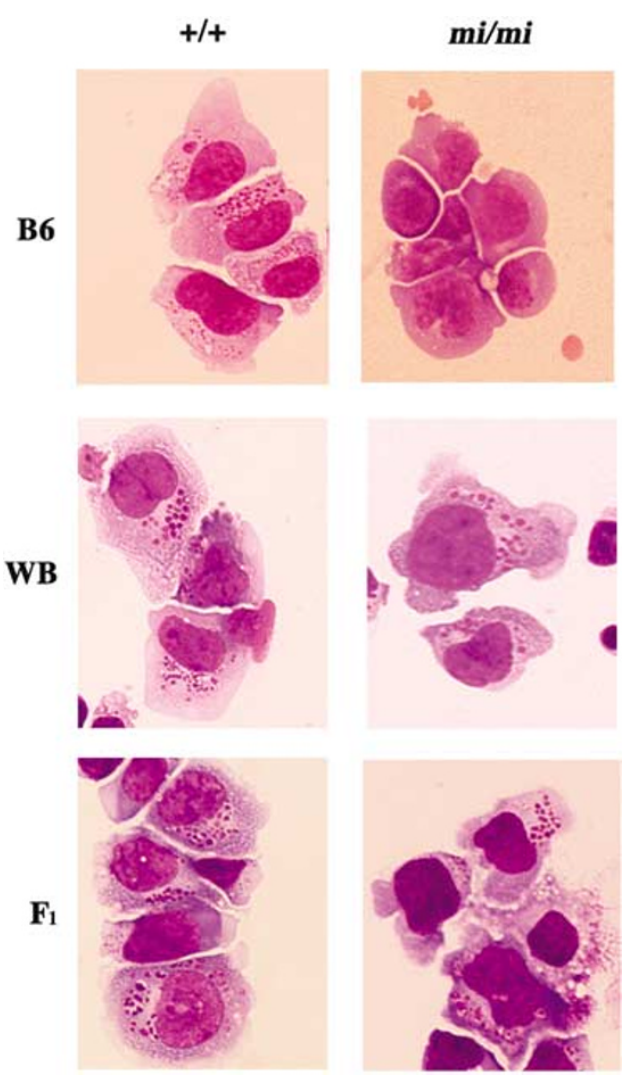

Figure 5 Appearance of LGLs in cultured spleen cells derived from B6- $+1+$, WB- $+/+$, WB-mi/mi, $\mathrm{WBB} \mathrm{F}_{1^{-}}+/+$and $\mathrm{WBB} \mathrm{F}_{1}-\mathrm{mi} / \mathrm{mi}$ mice, but not in those of B6-mi/mi mice. After the culture with IL-2 and IL-18 for 7 days, spleen cells of B6- $+/+$, B6-mi/mi, WB- $+/+$, WB-mi/mi, $\mathrm{WBB}^{-} \mathrm{F}_{1^{-}}+/+$and $\mathrm{WBB}^{-} \mathrm{F}_{1}-$ $\mathrm{mi} / \mathrm{mi}$ mice were collected, stained with Giemsa solution and examined under an optical microscope. A representative field is shown.

compensating factor(s). Further analysis, including gene chip and promoter analyses of Gr B and Pfn genes between $\mathrm{B} 6$ and $\mathrm{WB}$ strains, could reveal information about such factor(s).

B6-mi/mi mice showed normal NK $1.1^{+}$ cell development but reduced NK activity. This indicated that the mi-MITF did not affect the 
development of NK $1.1^{+}$cells but inhibited NK activity. Recently, several knockout mice, such as IL12, IL-18 and CCAAT/enhancer-binding protein $\gamma(\mathrm{C} /$ EBP $\gamma$ ) knockout mice, have been reported to show normal NK $1.1^{+}$cell development but reduced NK activity. ${ }^{37-39}$ The mi-MITF may inhibit some molecules regulated by IL-12, IL-18 and C/EBP $\gamma$.

The formation of cytoplasmic granules of NK cells was severely impaired in B6-mi/mi mice, but not in WB-mi/mi and $\mathrm{WBB} \mathrm{F}_{1}-\mathrm{mi} / \mathrm{mi}$ mice. Since NK cells of Pfn gene knockout mice had cytoplasmic granules ${ }^{40}$ deficient granule formation in B6-mi/mi mice was not attributable to the impaired expression of Pfn mRNA. The NK activity and the granule formation were impaired in $\mathrm{mi} / \mathrm{mi}$ mice of $\mathrm{B} 6$ genetic background, but not in $\mathrm{mi} / \mathrm{mi}$ mice of $\mathrm{WB}$ genetic background. Since the phenotypes of $\mathrm{WBB} \mathrm{F}_{1}-\mathrm{mi} / \mathrm{mi}$ mice were similar to those of WB$\mathrm{mi} / \mathrm{mi}$ mice, these phenotypes were inherited dominantly.

Taken together, the impaired cytotoxic activities of CMCs and NK cells were found only in the B6 strain, and the impairment was caused by the presence of the inhibitory MITFs (mi-MITF and $M^{o r}$-MITF) but not by the absence of normal MITF. The inhibitory effect of the mi-MITF appeared to be compensated in WB strain but not in B6 strain. Further analysis with mice of strains other than B6 and WB will be helpful in revealing the compensating factor(s) for inhibitory MITFs more precisely.

\section{Acknowledgement}

We thank Ms T Sawamura for technical assistance. This work was supported by grants from the Ministry of Education, Culture, Sports, Science and Technology.

\section{References}

1 Hodgkinson CA, Moore KJ, Nakayama A, et al. Mutations at the mouse microphthalmia locus are associated with defects in a gene encoding a novel basic-helix-loop-helix-zipper protein. Cell 1993;74:395-404.

2 Hughes JJ, Lingrel JB, Krakowsky JM, et al. A helixloop-helix transcription factor-like gene is located at the mi locus. J Biol Chem 1993;268:20687-20690.

3 Silvers WK. The Coat Colors of Mice: A Model for Mammalian Gene Action and Interaction. SpringerVerlag: New York, 1979.

4 Green MC. Catalog of mutant genes and polymorphic loci. In: Lyon MF, Searle AG (eds). Genetic Variants and Strains of the Laboratory Mouse. Gustav Fischer Verlag: Stuttgart, 1981, pp. 158-160.

5 Steingrimsson E, Moore KJ, Lamoreux ML, et al. Molecular basis of mouse microphthalmia (mi) mutations helps explain their developmental and phenotypic consequences. Nat Genet 1994;8:256-263.
6 Hemesath TJ, Steingrimsson E, McGill G, et al. Microphthalmia, a critical factor in melanocyte development, defines a discrete transcription factor family. Gene Dev 1994;8:2770-2780.

7 Nii A, Steingrimsson E, Copeland NG, et al. Mild osteopetrosis in the microphthalmia-oak ridge mouse: a model for intermediate autosomal recessive osteopetrosis in humans. Am J Pathol 1995;147:1871-1882.

8 Kim DK, Morii E, Ogihara H, et al. Different effect of various mutant MITF encoded by $\mathrm{mi}, \mathrm{Mi}^{\text {or }}$, or $\mathrm{Mi}^{\text {wh }}$ allele on phenotype of murine mast cells. Blood 1999;93:4179-4186.

9 Tachibana M, Hara Y, Vyas D, et al. Cochlear disorder associated with melanocyte anomaly in mice with a transgenic insertional mutation. Mol Cell Neurosci 1992;3:433-445.

10 Stenvens J, Loutit JF. Mast cells in spotted mutant mice ( $W, P h, m i)$. Proc R Soc Lond 1982;215:405-409.

11 Stechschulte DJR, Sharma KN, Dileepan KM, et al. Effect of the mi allele on mast cells, basophils, natural killer cells, and osteoclasts in C57Bl/6J mice. J Cell Physiol 1987;132:565-570.

12 Ebi Y, Kasugai T, Seino Y, et al. Mechanism of mast cell deficiency in mutant mice of $\mathrm{mi} / \mathrm{mi}$ genotype: an analysis by co-culture of mast cells and fibroblasts. Blood 1990;75:1247-1251.

13 Ito A, Morii E, Kim DK, et al. Inhibitory effect of the transcription factor encoded by the mi mutant allele in cultured mast cells of mice. Blood 1999;93:1189-1196.

14 Ito A, Kataoka TR, Kim DK, et al. Inhibitory effect on natural killer activity of microphthalmia transcription factor encoded by the mutant $\mathrm{mi}$ allele of mice. Blood 2001;97:2075-2083.

15 Steingrimsson E, Tessarollo L, Pathak B, et al. MITF and Tfe3, two members of the MITF-Tfe family of bHLH-Zip transcription factors, have important but functionally redundant roles in osteoclast development. Proc Natl Acad Sci USA 2002;99:4477-4482.

16 Kitamura Y, Morii E, Jippo T, Ito A. mi-transcription factor as a regulator of mast cell differentiation. Int J Hematol 2000;71:197-202.

17 Morii E, Ogihara H, Oboki K, et al. Effect of a large deletion of the basic domain of mi transcription factor on differentiation of mast cells. Blood 2001;98: 2577-2579.

18 Morii E, Ogihara H, Kim DK, et al. Importance of leucine zipper domain of $\mathrm{mi}$ transcription factor (MITF) for differentiation of mast cells demonstrated using $m i^{c e} / \mathrm{mi}^{c e}$ mutant mice of which MITF lacks the zipper domain. Blood 2001;97:2038-2044.

19 Morii E, Oboki K, Jippo T, et al. Additive effect of mouse genetic background and mutation of MITF gene on decrease of skin mast cells. Blood 2003;101: 1344-1350.

20 Russell ES, Lawson FA. Selection and inbreeding for longevity of a lethal type. J Hered 1959;50:19-25.

21 Russell ES. Hereditary anemias of the mouse: a review for geneticists. Adv Genet 1979;20:357-459.

22 Nakahata T, Spicer SS, Cantey JR, et al. Clonal assay of mouse mast cell colonies in methylcellulose culture. Blood 1992;60:352-362.

23 Hattori M, Suda T, Iizuka M, et al. Generation of continuous large granular lymphocyte lines by interleukin 2 from the spleen cells of mice infected with Moloney leukemia virus: involvement of interleukin 3. J Exp Med 1987;166:833-849. 
24 Djeu JY, Heibaugh JA, Holden HT, et al. Augmentation of mouse natural killer cell activity by interferon and interferon inducers. J Immunol 1979;122: 175-181.

25 Tomura M, Zhou XY, Maruo S, et al. A critical role for IL-18 in the proliferation and activation of $\mathrm{NK}$ $1.1^{+} \mathrm{CD}^{-}$cells. J Immunol 1998;160:4738-4746.

26 Bissonnette EY, Befus AD. Inhibition of mast cellmediated cytotoxicity by IFN $-\alpha / \beta$ and $-\gamma$. J Immunol 1990;145:3385-3390.

27 Kiessling R, Klein E, Wigzell H. 'Natural' killer cells in the mouse, I. Cytotoxic cells with specificity for mouse Moloney leukemia cells. Specificity and distribution according to genotype. Eur J Immunol 1975;5:112-117.

28 Kataoka TR, Morii E, Oboki K, et al. Dual abnormal effects of mutant MITF encoded by $\mathrm{Mi}^{\text {wh }}$ allele on mouse mast cells: decreased but recognizable transactivation and inhibition of transactivation. Biochem Biophys Res Commun 2002;297:111-115.

29 Kumagai K, Itoh K, Suzuki R, et al. Studies of murine large granular lymphocytes, I: identification as effector cells in $\mathrm{NK}$ and $\mathrm{K}$ cytotoxicities. J Immunol 1982;129:388-394.

30 Hackett J, Tutt M, Lipscomb M, et al. Origin and differentiation of natural killer cells, II: functional and morphological studies of purified NK-1.1 $1^{+}$cells. J Immunol 1986;136:3124-3131.

31 Koo GC, Peppard JR, Hatzfeld A. Ontogeny of NK-1 ${ }^{+}$ natural killer cells, I: proportion of $\mathrm{NK}-1^{+}$cells in fetal, baby, and old mice. J Immunol 1982;129:867-871.

32 Tajima Y, Moore MA, Soares V, et al. Consequences of exclusive expression in vivo of Kit-ligand lacking the major proteolytic cleveage site. Proc Natl Acad Sci USA 1998;95:11903-11908.

33 Kunisada T, Lu SZ, Yoshida H, et al. Murine cutaneous mastocytosis and epidermal melanocytosis induced by keratinocyte expression of transgenic stem cell factor. J Exp Med 1998;187:1565-1573.

34 Babichuk CK, Duggan BL, Bleackley RC. In vivo regulation of murine granzyme $\mathrm{B}$ gene transcription in activated primary $\mathrm{T}$ cells. $\mathrm{J}$ Biol Chem 1996;271:16485-16493.

35 Ogihara H, Morii E, Kim D-K, et al. Inhibitory effect of the transcription factor encoded by the mutant mi microphthalmia allele on transactivation of mouse mast cell protease 7 gene. Blood 2001;97:645-651.

36 Ogihara H, Kanno T, Morii E, et al. Synergy of PEBP2/ $\mathrm{CBF}$ with mi transcription factor (MITF) for transactivation of mouse mast cell protease 6 gene. Oncogene 1999;18:4632-4639.

37 Magram J, Connaughton SE, Warrier RR, et al. IL-12deficient mice are defective in IFN $\gamma$ production and type 1 cytokine responses. Immunity 1996;4:471-481.

38 Williams NS, Klem J, Puzanov IJ, et al. Natural killer cell differentiation: insights from knockout and transgenic mouse models and in vitro systems. Immunol Rev 1998;165:47-61.

39 Kaisho T, Tsutsui H, Tanaka T, et al. Impairment of natural killer cytotoxic activity and interferon $\gamma$ production in CCAAT/enhancer binding protein $\gamma$ deficient mice. J Exp Med 1999;190:1573-1581.

40 Lowin B, Beermann F, Schmidt A, et al. A null mutation in the perforin gene impairs cytolytic $\mathrm{T}$ lymphocyte- and natural killer cell-mediated cytotoxicity. Proc Natl Acad Sci USA 1994;91:11571-11575. 